\title{
Depressed antithrombin III biological activity in opiate addicts
}

\author{
ANTONIO CERIELLO, PATRIZIA DELLO RUSSO, FRANCESCO CURCIO, \\ ANGELO TIRELLI, DARIO GIUGLIANO
}

From the Istituto di Patologia Speciale Medica, I Facoltà di Medicina - Università di Napoli, Naples, Italy.

SUMMARY Antithrombin III activity was significantly decreased in opiate addicts, but no difference was found between addict and control groups in antithrombin III plasma concentration. Moreover, glycosylated haemoglobin concentration was increased in opiate addicts, but no correlation between glycosylated haemoglobin and antithrombin III activity was found.

These data show that in opiate addicts there is depressed biological activity of antithrombin III. Further characterisation of the molecular changes in antithrombin III in addicts is needed to establish whether the impaired activity is affected by altered glucose metabolism.

Decreased antithrombin III activity,' correlated with altered glucose metabolism, has been reported in diabetes; this decreased activity occurs in the presence of normal concentrations of proteins. Impaired glucose tolerance in opiate addicts has been shown by low values of glucose utilisation ${ }^{2}$ and by increased concentrations of glycosylated haemoglobin $^{3}$ and glycosylated proteins. ${ }^{4}$ We have therefore measured the concentration as well as the biological activity of antithrombin III in opiate addicts and have correlated the results with glycosylated haemoglobin values, which closely reflect glucose tolerance. ${ }^{5}$

\section{Material and methods}

Nineteen male addicts, who were taking heroin by intravenous injection and were attending our unit regularly for treatment, were studied. All were volunteers, aged 18-27 years, with normal body weights $(58-68 \mathrm{~kg})$, and with no family history of diabetes. The total heroin intake in $24 \mathrm{~h}$ ranged between 20 and $200 \mathrm{mg}$.

Twenty healthy men, matched for age (18-28 years) and weight (56-69 kg), acted as controls.

Citrated venous blood was obtained from a forearm vein, without stasis, after $12 \mathrm{~h}$ fasting. Plasma glucose concentration was measured by the glucose oxidase method. Glycosylated haemoglobin was determined with the rapid chromatographic method of Welch and Boucher. ${ }^{\circ}$

Accepted for publication 6 June 1984
Antithrombin III activity was evaluated as heparin cofactor activity according to Abildgaard. ${ }^{7}$ The antithrombin III activity was expressed as a percentage of normal plasma activity.

Antithrombin III protein concentration was determined by radial immunodiffusion according to Mancini $e t$ al $^{7 \mathrm{a}}$ on the M-Partigen agarose plate (Behring Diagnostics).

Statistical comparisons were made by simple linear regression and Student's $t$ test for unpaired data.

\section{Results}

Glycosylated haemoglobin concentration was increased $(p<0.001)$ and antithrombin III activity decreased $(p<0.001)$ in addicts, while no difference was found in antithrombin III and glucose plasma concentrations (Table). Furthermore, as previously found ${ }^{8}$ there was a good correlation between antithrombin III activity and antithrombin III protein concentration in healthy controls $(r=0.93$; $p<0.001$ ) (Fig. 1), but not in addicts ( $r=0.16$; $\mathrm{p}=\mathrm{NS}$ ) (Fig. 2). No significant correlation was found between antithrombin III activity and glycosylated haemoglobin and plasma glucose concentrations or heroin dose in addicts.

\section{Discussion}

Antithrombin III is believed to be one of the major regulator proteins of the coagulation system. ${ }^{9} \mathrm{~A}$ functional defect has recently been described - 
Concentrations of plasma glucose and glycosylated haemoglobin and antithrombin III concentration and activity in opiate addicts and controls

\begin{tabular}{|c|c|c|c|}
\hline & $\begin{array}{l}\text { Addicts } \\
\text { (19) }\end{array}$ & $p$ & $\begin{array}{l}\text { Controls } \\
\text { (20) }\end{array}$ \\
\hline $\begin{array}{l}\text { Plasma glucose concentration }(\mathrm{mmol} / \mathrm{l}) \\
\text { Glycosylated haemoglobin }(\%) \\
\text { Antithrombin III activity }(\%) \\
\text { Antithrombin III concentration }(\mathrm{mg} / 100 \mathrm{ml})\end{array}$ & $\begin{aligned} 4 \cdot 58 & \pm 0 \cdot 74 \\
7 \cdot 1 & \pm 0 \cdot 15 \\
87 \cdot 62 & \pm 12 \cdot 23 \\
30 \cdot 72 & \pm 3 \cdot 74\end{aligned}$ & $\begin{array}{l}\text { NS } \\
\mathrm{p}<0.001 \\
\text { NS } \\
\text { N.001 }\end{array}$ & $\begin{aligned} 4 \cdot 64 & \pm 0 \cdot 81 \\
6 \cdot 2 & \pm 0 \cdot 18 \\
104 \cdot 9 & \pm 8 \cdot 94 \\
31 \cdot 32 & \pm 2 \cdot 35\end{aligned}$ \\
\hline
\end{tabular}

Results are given as mean $\pm \mathrm{SD}$.

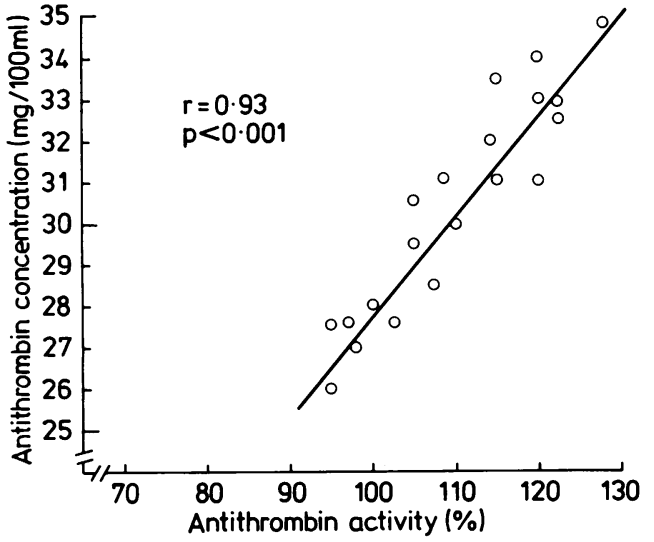

Fig. 1 Correlation between antithrombin 'I activity and antithrombin III protein concentration in heulthy controls.

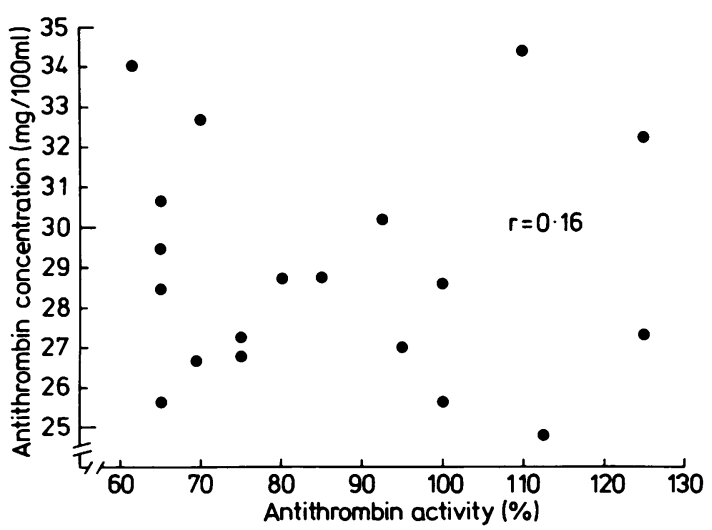

Fig. 2 Correlation between antithrombin III activity and antithrombin III protein concentration in opiate addicts.

antithrombin III Budapest - which is associated with venous thromboembolism, ${ }^{10}$ and thromboembolic episodes in opiate addicts have been reported."

Our data suggest the existence of depressed antithrombin III biological activity in opiate addicts and may explain the findings of changes in the blood coagulation system in addicts. ${ }^{1213}$ These changes are similar to those found in diabetics, who have increased platelet aggregation ${ }^{14}$ and increased fibrinogen values. ${ }^{15}$ Moreover, these data highlight other similarities between opiate addicts and diabetics. ${ }^{16} 17$

To our knowledge this is the first demonstration that chronic heroin administration interferes adversely with protein biological function. Characterisation of the molecular alteration in antithrombin III in opiate addicts is needed to establish whether the impaired antithrombin III activity is affected, as in diabetics, ${ }^{1}$ by altered glucose metabolism.

\section{References}

' Ceriello A, Dello Russo P, Zuccotti C, et al. Decreased antithrombin III activity in diabetes may be due to non-enzymatic glycosylation. A preliminary report. Thromb Haemostas 1983;50:633-4.

2 Passariello N, Giugliano D, Quatraro A, et al. Glucose tolerance and hormonal responses in heroin addicts. A possible role for endogenous opiates in the pathogenesis of non-insulin dependent diabetes. Metabolism 1983;32:1163-5.

${ }^{3}$ Ceriello A, Giugliano D, Dello Russo P, Sgambato S, D' Onofrio $F$. Increased glycosylated haemoglobin $A_{1}$ in opiate addicts: evidence of hyperglycaemic effect of morphine. Diabetologia 1982;22:379.

${ }^{4}$ Ceriello A, Dello Russo P, Curcio F, Rossano P. Increased glycosylated protein in opiate addicts. Diabetes Care 1984; 7:104-5.

${ }^{5}$ Verrillo A, de Teresa A, Golia R, Nunziata V. The relationship between glycosylated haemoglobin and various degrees of glucose intolerance. Diabetologia 1983;24:391-3.

- Welch SG, Boucher BS. A rapid microscale method for the measurement of $\mathrm{Hb} \mathrm{A}_{1(\mathrm{a}+\mathrm{b}+\mathrm{c})}$. Diabetologia 1978;14:209 12.

' Abildgaard U, Lie M, Odegärd OR. Antithrombin (heparin co-factor) assay with "new" chromogenic substrates (S-2238 and Chromozym TH). Thromb Res 1977;11:549-54.

7a Mancini G, Carbonara AO, Heremans JF. Immunochemical quantitation of antigens by single radial immunodiffusion. Immunochemistry 1965; 2:235-42.

${ }^{8}$ Hedner U, Nilsson IM. Antithrombin III in a clinical material. Thromb Res 1973;3:631-45.

' Rosemberg RD, Damus PS. The purification and mechanism of action of human antithrombin-heparin cofactor. J Biol Chem $1973 ; 248: 6490-8$ 
10 Sas G, Pepper DS, Cash J. Further investigations on antithrombin III Budapest. Thromb Diath Haemorrh 1975;33:564-72.

" Cherubin CE. The medical sequelae of narcotic addiction. Ann Intern Med 1967;67:23-88.

12 Passariello N, Giugliano D, Ceriello A, Misso L, Quatraro A. Increased platelet aggregation in opiate addicts. Blood 1982;60:276.

${ }^{13}$ Ceriello A, Dello Russo P, Niola O, Capezzuto C, Schimizzi S. Fibrinogen levels in opiate addicts. Thromb Haemostas 1983;50:755.

it Sagel J, Colwell JA, Crook L, Laimins M. Increased platelet aggregation in early diabetes mellitus. Ann Intern Med 1975;82: 733-5. is Coller BS, Frank DN, Milton RC. Plasma co-factors of platelet function. Correlation with diabetic retinopathy and haemoglobins $\mathrm{A}_{1 \mathrm{a}-\mathrm{c}}$. Ann Intern Med 1978;88:311-5.

${ }^{16}$ Dello Russo P, Ceriello A, Passariello N, Giugliano D. Haemoglobin $A_{1}$ in addicts. Ann Intern Med 1982;96:536.

" Ceriello A, Dello Russo P, Curcio F, Petringa D, Varriale M, D' Ippolito S. Morphine, diabetes and lipid metabolism. Arch Intern Med 1983;143:1070.

Requests for reprints to: Dr Antonio Ceriello, Istituto di Patologia Speciale Medica, I Facoltà di Medicina, Piazza Miraglia - 80138 Naples, Italy.

\section{The August 1984 issue}

\section{THE AUGUST 1984 ISSUE CONTAINS THE FOLLOWING PAPERS}

\section{Review article}

Glycosylated haemoglobin: measurement and clinical use I PEAcOCK

Proximal renal tubular function in myelomatosis: observations in the fourth Medical Research Council trial EH COOPER, MA FORBES, RA CROCKSON, ICM MACLENNAN

Plasma ionised calcium in preterm infants: comparison with adults PD MAYNE, JA JAMES, IC BARNES, IZ KOVAR

Early plasma protein and mineral changes after surgery: a two stage process MA MYERS, A FLECK, B SAMPSON, CM COLLEY, J BENT, G HALL

Maternal serum $\alpha_{1}$-antitrypsin concentrations in normotensive and hypertensive pregnancies $M$ LEGGE, GB DUFF, HC POTTER, MM HOETJES

Haemorrheological effects of prostaglandin $E_{1}$ infusion in Raynaud's syndrome GS LUCAS, MH SIMMS, NM CALDWELL, SJC ALEXANDER, J STUART

Platelet impedance aggregation in whole blood and its inhibition by antiplatelet drugs IJ MACKIE, R JONES, SJ MACHIN

Consumption of fibrinolytic proteins in menstrual fluid from women with normal menstrual blood loss SA CEDERHOLM-WILLIAMS, MCP REES, AC TURNBULL

Measurement of cross linked fibrin derivatives in plasma: an immunoassay using monoclonal antibodies AN WHITAKER, MJ ELMS, PP MASCI, PG BUNDESEN, DB RYLATT, AJ WEBBER, IH BUNCE

Assessment of the value of a competitive protein binding radioassay of folic acid in the detection of folic acid deficiency BJ BAIN, SN WICKRAMASINGHE, GN BROOM, RA LITWINCZUK, J SIMS

Distribution of laminin, fibronectin, and interstitial collagen type III in soft tissue tumours AJ D' ARDENNE, P KIRKPATRICK, BC SYKES

An investigation of $\beta$ enolase as a histological marker of rhabdomyosarcoma JANICE A ROYDS, $\mathrm{S}$ VARIEND, WR TIMPERLEY, CB TAYLOR

Nature of non-B, non-T lymphomas: an immunohistological study on frozen tissues using monoclonal antibodies G PALLESEN, PCL BEVERLEY, EB LANE, M MADSEN, DY MASON, H STEIN

Morphological and immunohistological changes in the skin in allogeneic bone marrow recipients JP SLOANE, JA THOMAS, SF IMRIE, DF EASTON, RL POWLES

Amine and peptide hormone production by lung carcinoid: a clinicopathological and immunocytochemical study FT BOSMAN, A BRUTEL DE LA RIVIERE, RWM GIARD, AAJ VERHOFSTAD, G CRAMER-KNIJNENBURG

Comparison of a commercial ELISA system with? restriction endonuclease analysis for typing herpes simplex virus KJ SMITH, CR ASHLEY, JM DARVILLE, J HARBOUR, APCH ROOME

Clostridium perfringens type $\mathrm{C}$ causing necrotising enteritis WPJ SEVERIN, AA de la FUENTE, MF STRINGER

Extragenital granuloma inguinale (Donovanosis) diagnosed in the United Kingdom: a clinical, histological, and electron microscopical study DV SPAGNOLO, PR COBURN, JJ CREAM, BS AZADIAN

\section{Technical methods}

Counterimmunoelectrophoresis in the diagnosis of whooping cough PC BORELAND, SH GILLESPIE

Sample collection for determination of plasma fibronectin concentration PEARL TCY TOY, MARION E REID

Advantages of fixed stored materials for immunoelectron microscopy, with special reference to the study of malignant lymphomas H AKATSUKA, K KITO, M SHAMOTO, T SUCHI

\section{Letters to the Editor}

Book reviews

Copies are still available and may be obtained from the PUBLISHING MANAGER, BRITISH MEDICAL ASSOCIATION, TAVISTOCK SQUARE, LONDON WC1H $9 \mathrm{JR}$, price $£ 5 \cdot 00$, including postage 